\title{
Analysis Of Regional Original Income Levels In Regional Financial Performance On Economic Growth In East Java Province
}

\author{
Muhammad Yasin \\ Universitas Teknologi Surabaya
}

\begin{abstract}
Economic growth is a process of changing a country's economic conditions on an ongoing basis towards better conditions for a certain period. Economic growth can also be interpreted as a process of increasing the production capacity of an economy that is realized in the form of an increase in national income. With a good Regional Financial Performance this is because the greater the Regional Original Revenues obtained from local taxes, regional levies, the results of the management of separated regional assets and other legal income and the smaller the loan and central assistance, the more independent the region. With the increasingly independent area, the economic growth in the area can experience an increase. This is because the region is able to manage economically, efficiently, and effectively as well as the lack of intervention by the central government. economic growth with This means that if the income of the region will also cause an increase in the achievement of economic growth. which is very flexible in terms of utilization causes the regions to be more flexible in planning the allocation of the budget for development activities in accordance with its economic agenda which includes the development of basic facilities and infrastructure that play a role in supporting optimal economic growth.
\end{abstract}

Keywords: Regional Original Revenue, Regional Financial Performance and Economic Growth

\section{INTRODUCTION}

Economic growth is a process of changing a country's economic conditions on an ongoing basis towards better conditions for a certain period. Economic growth can also be interpreted as a process of increasing the production capacity of an economy that is realized in the form of an increase in national income. Whereas Revenue Regional Original which is usually the main driver of growth, in 2016 only grew $2.32 \%$ (up Rp345 billion).

The Fiscal Autonomy Degree Ratio in East Java Province is still in the good category, reflected in the $62.56 \%$ of the revenue budget which is local revenue. Local taxes are still the largest component of regional own-source revenues $(82.51 \%$ share of total regional own-source revenues), but growth has slowed to $2.03 \%$ after growing $18.35 \%$ in 2015 . The reduction in tax revenue targets, among others, was implemented in the tax targets (motor vehicle transfer fees) and (Motor Vehicle Fuel Tax). The decrease in the regional tax revenue target is indicated in line with the efforts of the Government of East Java Province to encourage economic activities of the community, which are predominantly dominated by household consumption.

Realized Local Revenue was $27.77 \%$, higher than the $26.86 \%$ in the second quarter of 2015 , driven by regional taxes which were realized at $27.82 \%$, higher than the same period in the previous year $(24.55 \%)$. The high realization of regional tax revenue is in line with the efforts of the East Java Government to increase taxpayers and law enforcement efforts related to taxation. In addition, the economy of East Java which began to accelerate in the second quarter of 2016 also had a positive impact on tax revenue. The increase in regional tax revenue is also reflected in an increase in private car sales in East Java, which grew 5.7\% this quarter. The East Java Provincial Government Expenditure Budget consists of a budget and a transfer budget. In the 2016 budget changes, both reached IDR24.75 trillion, up 1.62\% compared to 2015 which 
amounted to IDR24.36 trillion. The increase occurred in the operating expenditure budget, while the capital expenditure and transfer budget declined. The operating expenditure budget was IDR 15.53 trillion, an increase of $12.96 \%$ compared to 2015 , with the largest increase in personnel expenditure (30.95\%), followed by grant expenditure $(25.41 \%)$ and social assistance expenditure $(12.59 \%)$.

\section{Formulation of the problem}

Researchers formulated a number of problems as follows:

1) What is the level of Local Own Revenue on the performance of Regional Finances in East Java Province.

2) What is the level of Local Own Revenue in Economic Growth in East Java Province.

3) Is there an influence of Regional Financial Performance on Economic Growth in East Java Province.

\section{Locally-generated revenue}

\section{LITERATURE REVIEW}

According to Mardiasmo in Fisanti (2013), regional own-source revenue is revenue obtained from the regional tax sector, regional levies, results of regionally-owned companies, the results of the management of separated regional assets, and other legitimate regional own-source revenues. Optimization in receiving Local Revenue should be supported by efforts by local governments to improve the quality of public services. Excessive exploitation of PAD will only burden the community, become a disincentive to the region and threaten the macro economy.

Local Original Revenue is a regional Government through its efforts to fulfill regional obligations, one of the objectives is to increase the economy which is expected to directly affect the quality of life of its people. In order to meet these objectives the government is expected to have its own financial system both in terms of revenue and expenditure so it does not depend on the central government.

\section{Regional Finance}

According to Tjahja Supriatna (2000), the definition of regional finance is the ability of the regional government to supervise the region to manage starting from planning, implementing, supervising, controlling, and evaluating various financial sources in accordance with its authority in the framework of implementing the principles of decentralization, deconcentration and co-administration in regional realized in the form of regional income and expenditure budgets. Meanwhile according to Government Regulation No. 105 of 2000, regional finance is "All rights and obligations of the region in the context of the administration of regional governments which can be valued in money including all forms of wealth related to the rights and obligations of the region, within the framework of the regional budget of revenue and expenditure

In the Law governing State Finances, there is an affirmation in the area of financial management that has implications for regional financial management arrangements, namely that the Regional Head (governor / regent / mayor) is the holder of regional financial management authority and is responsible for the management of regional finances as part of regional government power. In exercising its authority, the regional head delegates part or all of the regional financial power to regional apparatus officials. Thus the regulation of regional financial management and accountability is inherent and becomes one with the regulation of regional government, namely in the Law on Regional Government 


\section{Regional financial performance}

Understanding Performance as stated by Bastian (2001: 329) is a picture of the level of achievement of the implementation of an activity / program / policy in realizing the goals, objectives, vision, and mission of the organization owed in the formulation of an organization's strategic scheme. In general it can also be said that performance is an achievement that can be achieved by an organization within a certain period, whereas according to Inpres No. 7 of 1999 concerning performance accountability of government agencies, performance is a picture of the level of achievement of the implementation of an activity / program / policy in realizing the goals, objectives, mission and vision of the organization.

This is because the greater the region's original income derived from local taxes, regional levies, the results of the management of separated regional assets and other legal income and the smaller the loan and central assistance, the more independent the region. With the increasingly independent area, the economic growth in the area can experience an increase. This is because the region is able to manage economically, efficiently, and effectively as well as the lack of intervention by the central government.

\section{Financial Management Objectives}

The objectives of local government financial management can be summarized as follows:

\section{Responsibility}

Accountability (accountability) local government must account for its financial duties to institutions or people with legitimate interests. The institution or person includes the central government, the regional legislative assembly (DPRD), the regional head (the person in charge of all administrative units) and the general public. The essential elements of responsibility include:

a. Validity, every financial transaction must be based on certain legal authority.

b. Supervision, effective procedures for safeguarding the wealth of money and goods, preventing diversion and misappropriation, and ensuring that all legitimate revenues are collected, clearly sourced and appropriately used.

\section{Fulfill financial obligations}

Regional finances must be structured in such a way as to be able to pay off all financial ties, short-term and long-term (including long-term loans).

\section{Honesty}

Financial matters must be left to honest employees, and opportunities to cheat are reduced.

\section{Results and usability}

The procedures for managing regional finances must be such that the program can be planned and implemented to achieve the objectives of the local government at the lowest possible cost and in the shortest time possible.

\section{Control}

Regional government finance officers, regional people's representative councils, and supervisory officers must exercise control so that all of the above objectives are achieved; they must strive to always get the information needed to monitor the implementation of revenues and expenditures and to compare revenues and expenditures with plans and targets. 


\section{Main Elements of Financial Management}

The elements of the local government financial system can be classified into two groups, namely:

\section{Periodic and legal elements}

Periodic elements include elements that are part of regular activities in a year, namely: compiling programs and budgets, spending and receiving budgets, handling money out and entering money, recording and reporting financial transactions. Legal elements include elements of regulating and monitoring periodic activities, namely: Financial laws and regulations, financial transactions and audits from within.

\section{Outer and inner elements}

External elements include supervision imposed on local governments by higher level supervisory officials (central government, and there is a Dati II by the provincial governor), based on laws, regulations and guidelines: ratification of the budget and financial regulations, reports on needs and financial audits of the outside. The internal element is the element of supervision and reporting that is held and carried out by the regional government for the guidance of local government finance officials. The most important elements are periodic procedures as mentioned above, along with self-formulated financial regulations and internal financial audits.

\section{Economic growth}

Economic Development is one of the efforts in order to support the implementation of one of the priorities listed in the National Development Priorities, namely to accelerate economic recovery and strengthen the foundation of sustainable and equitable economic development based on a populist system. This priority setting is based on the problems and challenges faced and the direction of policies in economic development, both short and medium term development (Propenas 2002-2004).

In general, economic growth can be interpreted as the development of activities in the economy that causes goods and services produced in the community to increase and the prosperity of the community to increase. Economic growth can also be interpreted as an increase in Gross Domestic Product (GDP) or Gross National Product (GNP) regardless of whether the increase is greater or smaller than the rate of population growth or whether changes in economic structure occur or not (Arsyad,1999). From some of the definitions above it can be concluded that economic growth is the ability of a country to provide the needs of goods and services to the community in large numbers so as to allow for an increase in living standards which also has an impact on reducing the unemployment rate in the long run. Todaro (2006) specifically mentions that there are three main factors or components of economic growth, namely capital accumulation, population growth, and matters relating to the increase in the workforce that are considered to be positively stimulating economic growth Level of Original Regional Revenue on Regional Financial Performance Against Economic Growth. Level of Regional Expenditure on Regional Financial Performance Against Economic Growth Strategy on Regional Financial Performance Towards Economic Growth Management on Regional Financial Performance Towards Economic Growth and Community Welfare.

\section{Research design}

\section{RESEARCH METHOD}

This approach uses qualitative and quantitative approaches. Qualitative approach 'is research on research that is descriptive and tends to use analysis. The process and meaning (subject perspective) is more highlighted in qualitative research. The theoretical foundation is used as a guide so that the focus of research is in accordance with the facts in the field. Quantitative 
approach is a research approach that collects and analyzes data in the form of numbers. Quantitative approach is a research approach that is objective, including the collection and analysis of quantitative data and using statistical testing methods (Hermawan, 2005).

Research Subjects

\section{Population}

The population consists of objects / subjects that have certain qualities and characteristics that are determined by researchers to be studied and then conclusions are drawn (Sugiyono, 2014, 80), so that the population is all Regency Cities in East Java Province

\section{Sample}

The sample is part of the number and characteristics possessed by the population. If the population is large, and researchers may not study everything that exists in the population, for example due to limited funds, manpower and time, then the researcher will take a sample of that population. What is learned from the sample, the conclusion will be applied to the population (Sugiyono, 2014, 81). The research sample is 29 regencies and 9 cities in East Java

\section{Research Limitation}

The research sample determined by purposive random sampling is a method of determining samples based on certain criteria in order to meet good sample requirements. These criteria are: Samples are 29 districts and 9 cities in East Java Province for 3 years Research Assumptions The research assumptions are using certain data collection information from Bapeda, East Java.

There are two kinds of data analysis techniques in quantitative research, namely descriptive statistics and inferential statistics. Inferential statistics include parametric and nonparametric statistics (Sugiono, 2014: 147). In this study more inferential statistics (often also called inductive statistics or probability statistics) is a statistical technique used to analyze sample data and the results are applied to the population (Sugiono, 2014: 148).

\section{Quantitative Analysis}

Data analysis in this study uses the PLS (Partial Least Square) version 3.0 M3 PLS (Partial Least Square) application developed first by the wold as a general method for estimating the path model using latent constructs with multiple indicators. PLS (Partial Least Square) is a powerful factor of indeterminacy of analytical methods because it does not assume the data must be of a certain scale measurement, the number of samples is small. PLS (Partial Least Square) can also be used to confirm theories.

Based on the research objectives, the hypothesis test design that can be made is a hypothesis test design in this study is presented based on the research objectives. The confidence level used is $95 \%$, so the level of precision or inaccuracy limits is $(\alpha)=5 \%=0.05$ and produces a ttable value of 1.96. So if the $t$-statistic value is smaller than the t-table value ( $t$-statistic $<1.96$ ), then $\mathrm{HO}$ is accepted and $\mathrm{Ha}$ is rejected and if the $\mathrm{t}$-statistic value is greater or equal to $\mathrm{t}$-table ( $\mathrm{t}$ statistic $>1.96)$, then Ho was refused and Ha was accepted.

\section{ANALYSIS AND DISCUSSION \\ There is a significant influence of Regional Original Revenues on regional financial performance in districts and cities throughout East Java}

Regional Original Income to Regional Financial Performance in districts and cities throughout East Java is not significant with a t-statistic of 1,755 $(<1.96)$. The original sample estimate 
value is negative in the amount of -0.355 , which indicates that the direction of the relationship between Regional Original Revenue to Regional Financial Performance is negative.

Can be interpreted as Regional Original Income Variables that have insignificant and negative relationships. This shows that the increasing amount of Regional Original Revenue received by several City Regencies in East Java has a negative influence on economic growth. Local Original Revenue according to Mardiasmo in Fisanti (2013) explains that Regional Original Revenue is obtained from the Regional Tax, Regional Retribution, Regional Owned Company Results, Regional Wealth Management Results which are separated and other valid regional income. From the sources it appears that the collection of local taxes and levies actually results in regional output reflected in the Gross Regional Domestic Product produced by various revenue sectors in the Regency / City that is not running optimally. According to Lewis in Ahyani (2010) The ineffectiveness of various regulations carried out by the government may indicate that there is no positive relationship between the various new levies and the seriousness of the local government in improving the quality of public services.

In addition, the imposition of costs for goods and services offered that must be borne by regional companies also contributes to reducing the output produced. With less than the maximum GDP produced by an area will certainly affect the level of Economic Growth in the area. because the level of Economic Growth is inseparable from the rate of increase in the Gross Regional Domestic Product of the area. So it is very important for local governments to maximize their revenue sectors so that they get the maximum output in each sector.

\section{There is a significant influence of Regional Original Revenues on economic growth in regencies and cities throughout East Java}

Regional Original Income to Economic Growth is significant with a t-statistic of 2,040 (> 1.96). The original sample estimate value is positive that is equal to 0.355 which shows that the direction of the relationship between the Regional Original Income to Economic Growth is positive.

Regional Original Revenues can be interpreted as revenue sourced from levies imposed by the region based on applicable regulations that can be imposed on any person or business entity both government and private owned because of the acquisition of services provided by the government. Therefore the region can impose levies in the form of tax revenues, levies, and other legal receipts regulated in the law. An increase in regional original income will result in an increase in the government's financial performance. This can occur in regencies / cities in East Java Province to emphasize the results of Regional Original Revenues originating from various sources that are managed by local governments in the form of legal tax, retribution and other receipts as regulated in the Law

\section{There is a significant influence of regional financial performance on economic growth in districts and cities throughout East Java}

Financial performance on economic growth is insignificant with a t-statistic of 1,068 $(<1.96)$. The original sample estimate value is negative, which is -0.165 , which indicates that the direction of the relationship between financial performance and economic growth is negative.

That financial performance has no significant effect on economic growth. This illustrates that financial performance has an important role in terms of increasing economic growth. Regional governments after autonomy have the authority to manage substantial funds and if they are not accompanied by financial performance or budget efficiency, the funds issued by regional governments are not in line with development priorities in their regions and tend to 
experience budget wastage. The central and regional governments continue to improve their budget efficiency every year by issuing policies and programs with the principles of good governance, transparency and accountability, such as reducing fuel subsidies and electricity subsidies, renewed regulations on official travel abroad, the auction of goods and services electronics, budget transparency through electronic media, increasingly stringent financial controls and audits and other policies so that development expenditures sourced from the components of the Regional Revenue and Expenditure Budget can drive the pace of the economy

\section{CONCLUSION}

This study examines local revenue against regional financial performance and economic growth in districts and cities throughout East Java. " Based on the results of the study found that:

1. Regional Original Revenue to Regional Financial Performance in districts and cities in East Java is not significant with a t-statistic of $1,755(<1.96)$. The original sample estimate value is negative in the amount of -0.355 , which indicates that the direction of the relationship between Regional Original Revenue to Regional Financial Performance is negative.

2. Regional Original Income to Economic Growth is insignificant with a t-statistic of 2,040 ( $>1.96$ ). The original sample estimate value is positive that is equal to 0.355 which shows that the direction of the relationship between the Regional Original Income to Economic Growth is positive.

3. Financial performance on economic growth is significant with a t-statistic of 1,068 $(<1.96)$. The original sample estimate value is negative, which is -0.165 , which indicates that the direction of the relationship between financial performance and economic growth is positive.

\section{SUGGESTION}

Suggestions that can be given by researchers based on the results of this study are as follows:

1. It is hoped that the Regional Governments in each Regency and City in East Java Province should pay more attention to how to improve the financial performance of the Region so that it can be expected to increase Regional Original Revenue (PAD) so that the economic growth of each regency and city in East Java Province can prosper.

2. Financial Performance in every Regency and City in East Java to be monitored by the Regional Head so that the financial can be maximized in Economic Growth in every Regency and City in East Java Province

3. It is expected that further research, studies or studies that will be carried out should include other variables to be developed.

4. The addition of new variables as independent variables, dependent variables and moderate variables is very important to complete the results of this study

\section{References}

Ahyani, Wahid. 2010. Analysis of the Effect of Local Revenue and Regional Expenditures on Regional Economic Growth, and Post-Implementation Regional Autonomy Implementation (Case Study in the Districts and Cities of Central Java Province). Thesis, Not Published. Brawijaya University

Arsyad, L. (1999) Introduction to Regional Economic Planning and Development, First Edition, BPFE, Yogyakarta. Bastian, Indra. 2001. Public Sector Accounting. BPFE Publisher, Gajah Mada University, Yogyakarta.

BPS, East Java Statistics in Numbers, Surabaya: East Java, Statistics Indonesia.

Imam Ghozali. 2014. Partial least squares concepts, methods and applications using PLP 4.0 Warp Program, Diponegoro University Publisher Agency, Semarang. 
Mardiasmo, 2002. "Regional Autonomy as an Effort to Strengthen the Base of the Regional Economy". Paper. Seminar on People's Economy Deepening.

Mardiasmo, 2004. Autonomy and Regional Financial Management. Andi. Yogyakarta.

The compilation and stipulation of the State Budget and Regional Budget according to Law No. 17 of 2003

Republic of Indonesia Government Regulation Number 105 of 2000 concerning equalization funds

Republic of Indonesia Government Regulation No. 105 of 2000 concerning regional financial management and accountability

Pipin Syarifin and Dedah Jubaedah. 2005. Local Government in Indonesia. Bandung: Loyal Reader CV

Supriatna Tjahja. 2000. Development and Poverty Strategies. Rineke Cipta. Jakarta.

Sugiyono 2014. Educational Research Methods Quantitative, Qualitative and R\&D Approaches. Bandung: Alfabeta.

Supriatna Tjahja. 2000. Development and Poverty Strategies. Rineke Cipta. Jakarta.

Todaro M.P. 2006. Third World Economic Development, Erlangga Publisher, Jakarta.

Todaro. M.P., 2000. Economic Development in the Third World (H. Munandar, Trans. Seventh Edition ed.). Jakarta: Erlangga.

2004. Journal of Development Economics. Vol. 5, No. 2, December 2004, p. 147-159.

,2004, Development Economics, Fourth Edition, Yogyakarta: STIE YKPN.

2004. Journal of Development Economics. Vol. 5, No. 2, December 2004, p. 147-159.

,2004, Development Economics, Fourth Edition, Yogyakarta: STIE YKPN.

BPS, East Java Statistics in Numbers, Surabaya: East Java, Statistics Indonesia. 